\title{
Multi-disciplinary approach for sediment dynamics study of active floodplains
}

\section{Approche multidisciplinaire de la dynamique sédimentaire des plaines d'inondation actives}

\author{
Emmanuèle Gautier*, Jeannine Corbonnois**, François Petit***, Gilles Arnaud-Fassetta****, \\ Daniel Brunstein*****, Stéphane Grivel*, Geoffrey Houbrechts***, Thierry Beck**
}

\begin{abstract}
This study reviews multi-disciplinary approaches developed on active floodplains in order to formulate their evolution model and sediment budget, at different time scales, from historical evolution to hydrological event, and spatial scales (floodplain, active channels and fluvial units). The main objective of the different case studies is to emphasize the need for coupling tools and methods in analysing active floodplain patterns, deposition and erosion rates with regards to hydrological functioning and impact of human activities. The first part of the paper is dedicated to methods that help us to characterize the construction of floodplains at a historical time-scale. The second part examines the functioning of active floodplains at a detailed spatial and time scales. Different case studies selected in European and American floodplains aim at highlighting the contribution and the limits of methods developed at various temporal and spatial scales. Multi-temporal analysis of fluvial planform allows to determine the recycling time of a floodplain (Beni River in Amazonia) or to evaluate the impact of a large flood (Rhône River). Historical sedimentation of floodplain may be estimated on the basis of specific elements present in sediments such as ironwork waste products in Belgian rivers. Different methods are used to evaluate sediment remobilization in fluvial beds at different time scales. Bathymetric and topographic surveys, digital elevation models document vertical movements of the fluvial bed (Beni, Moselle and Loire Rivers) at pluri-annual and annual scales; they allow the calculation of sediment budgets. At a longer time scale, bedload progression has been evaluated in Ardenne rivers using slag elements.
\end{abstract}

Key words : active floodplain, methodology, sediment budget.

\section{Résumé}

Cet article de synthèse présente différentes approches multidisciplinaires mises en auvre sur des plaines d'inondation actives afin d'en déterminer le modèle d'évolution, le budget sédimentaire à différents pas de temps (de l'évolution historique à l'événement hydrologique) et à différentes échelles spatiales (de l'ensemble de la plaine à celle du chenal actif et de l'unité fluviale). Le principal objectif des études de cas présentées est de montrer la complémentarité des outils et méthodes dans l'analyse des schémas d'évolution des plaines d'inondation, des taux d'érosion et d'accumulation, en lien avec le fonctionnement hydrologique et l'impact des activités humaines. La première partie de l'article est consacrée aux méthodes permettant de caractériser la construction des plaines à des pas de temps historiques. La seconde partie de l'article analyse le fonctionnement des plaines d'inondation actives sur des échelles spatiales et temporelles fines. Les différentes études de cas sélectionnées dans des plaines européennes et américaines cherchent à mettre en évidence les apports et limites respectifs des analyses mises en auvre. L'analyse des formes fluviales en plan permet d'estimer le temps de recyclage de la plaine (exemple de la rivière Beni en Amazonie) ou bien encore, d'évaluer l'impact d'une grande crue (cas du Rhône en 2003). La sédimentation historique de la plaine et la vitesse de transfert de la charge solide dans le cours d'eau peuvent être estimées par l'utilisation de certains éléments spécifiques, comme les scories métalliques rejetées dans des rivières de l'Ardenne belge. L'évaluation annuelle et pluriannuelle de la mobilité verticale des lits fluviaux et de la remobilisation de la charge solide peut s'appuyer sur des relevés bathymétriques et topographiques, ainsi que sur l'élaboration de modèles numériques de terrain (Beni, Loire et Moselle), qui permettent d'établir des bilans sédimentaires.

Mots clés : plaine d'inondation active, méthodologie, bilan sédimentaire.

\footnotetext{
* Université Paris 8, CNRS UMR 8591, Laboratoire de Géographie Physique, 1 place Aristide-Briand, 92195 Meudon Cedex. Courriel : emmanuele.gautier@cnrs-bellevue.fr, stephane.grivel@cnrs-bellevue.fr

** Université du Maine, GREGUM, UMR 6590 ESO, avenue Olivier-Messiaen, 72085 Le Mans Cedex 9. Courriel : Jeannine.Corbonnois@univlemans.fr, thiebeck@modulonet.fr

*** Université de Liège, Laboratoire d'Hydrographie et de Géomorphologie fluviatile, Géomorphologie régionale, Allée du 6 août, 2 , Bât. B 11, Sart Tilman B 4000 Liège.Courriel : Francois.Petit@ulg.ac.be, g.houbrechts@ulg.ac.be

**** Université Paris 7, CNRS UMR 8586 PRODIG, 105 rue de Tolbiac, 75013 Paris. Courriel : fassetta@univ-paris-diderot.fr

***** CNRS UMR 8591, Laboratoire de Géographie Physique, 1 place Aristide-Briand, 92195 Meudon Cedex. Courriel : daniel.brunstein@cnrsbellevue.fr
} 


\section{Version française abrégée}

On entend par plaine d'inondation active un espace régulièrement soumis aux inondations et aux dépôts de sédiments apportés par débordement du cours d'eau (Leopold et Wolman, 1957 ; Lewin, 1978 ; Nanson et Croke, 1992). La régénération des plaines d'inondation actives s'effectue à la fois par des processus de destruction (érosion des berges, ouverture de nouveaux bras) et de construction (colmatage progressif des chenaux et dépôts de débordement). La principale difficulté de l'étude des dynamiques sédimentaires réside dans le fait que les modes de transfert et les temps de résidence des sédiments ne sont pas les mêmes dans la plaine s.s. et la bande active. L'article repose sur la présentation de quelques approches systémiques développées à propos de plaines inscrites dans des contextes physiques et anthropiques très différents. L'objectif de ces approches est d'établir le bilan sédimentaire des plaines d'inondation actives à différents pas de temps, de l'échelle historique à celle de l'événement hydrologique, et d'espace, de l'ensemble de la plaine à celle de la forme fluviale.

La première partie de l'article est consacrée aux méthodes permettant de caractériser la construction des plaines à des pas de temps historiques (pluri-décennaux, voire pluriséculaires). Le fondement de l'approche est l'analyse historique de l'évolution des formes en plan; l'intégration dans des SIG des données obtenues à partir des images satellites et des photographies aériennes a ouvert la voie à une quantification beaucoup plus précise des surfaces érodées et sédimentées, ce qui permet de calculer le "temps de recyclage de la plaine " (notion centrale créée par L. Mertes et al., 1996). Ainsi sur les plaines de l'Amazonie moyenne et inférieure, ce temps de recyclage est de 1000 à 4000 ans, alors qu'il est de 40 à 100 fois plus rapide dans les plaines situées à l'amont (fig. 1). Si elle est pertinente sur les systèmes fluviaux dominés par les processus latéraux (migration de la bande active, accrétion latérale des systèmes à style fluvial en tresses ou à méandres), cette approche est peu adaptée aux plaines caractérisées par des processus d'accrétion verticale et une bande active peu mobile.

D'autres méthodes et outils ont été mis en ceuvre pour déterminer les taux d'érosion et de sédimentation sur des pas de temps pluriannuels. Ainsi, les relevés topographiques et bathymétriques apportent des données particulièrement précises sur la mobilité verticale du lit fluvial et sur les taux d'érosion et de sédimentation. Sur la Loire moyenne, des levés topographiques espacés de 25 à 30 ans ont permis de montrer que l'enfoncement du chenal principal depuis les années 1970 s'est accompagné d'une forte accrétion verticale sur les îles jeunes et sur les berges (fig. 2). Le profil en long de la Moselle depuis les années 1980 témoigne d'un enfoncement généralisé du lit, avec cependant des zones très contrastées (fig. 3). La connaissance des rythmes d'érosion et de sédimentation des différentes unités fluviales est une donnée indispensable à la gestion des corridors fluviaux. De nombreux hydrosystemes fluviaux, comme c'est particulièrement le cas en France depuis les années 1950, souffrent d'un abaissement accéléré du plancher alluvial qui met en péril la ressource en eau, la biodiversité des zones humides et aquatiques, mais aussi les digues de protection et les ponts. Ces levés topographiques ont cependant quelques défauts, notamment leur durée et la difficulté de l'entreprise. De plus, ils apportent des données très localisées qu'il sera difficile d'extrapoler à l'ensemble des unités fluviales.

Pour analyser les bilans d'érosion et de sédimentation sur des pas de temps plus longs, il est possible d'utiliser certains marqueurs, d'origine naturelle ou anthropique, comme c'est le cas dans les rivières de l'Ardenne belge. Les scories métalliques rejetées dans ces rivières depuis le 14 e siècle ont été étudiées dans plusieurs plaines d'inondation du bassin de l'Ourthe et de la Meuse, ce qui nous a permis de mettre en évidence des taux de sédimentation de 15 à $20 \mathrm{~cm}$ par siècle. De plus, les dépôts postérieurs au Moyen Âge, plus épais que les couches sous-jacentes, témoignent bien d'un apport sédimentaire accru dans les plaines sous l'effet de la pression anthropique.

La seconde partie de l'article analyse le fonctionnement des plaines d'inondation actives sur des pas de temps plus courts. L'estimation des bilans sédimentaires porte plus spécifiquement sur le fonctionnement des chenaux actifs, qui jouent un rôle majeur dans les transferts de sédiments (Reid et Dunne, 2003). La recherche répond alors à deux grands enjeux. D'une part, il s'agit d'évaluer l'efficacité des écoulements et plus précisément le rôle des grandes crues qui perturbent lourdement et durablement les corridors fluviaux. D'autre part, on cherche à connaître la capacité de réajustement morphodynamique des hydrosystèmes fluviaux aux perturbations anthropiques. Trois études de cas sont présentées. L'analyse des surfaces inondées, des volumes érodés et déposés lors de la grande crue de décembre 2003 $d u$ Rhône a demandé le croisement de plusieurs sources d'information et de méthodes : images satellites pour l'analyse à moyenne échelle et relevés de terrain (formes et sédiments) pour la caractérisation à grande échelle. Il apparaît ainsi que dans la plaine, les bilans sédimentaires ont été positifs, l'accumulation ayant excédé largement l'érosion. De plus, les dépôts formés dans les deltas de rupture de levée ont été les principaux responsables de cette sédimentation (fig. 4). Les mesures directes du transit sédimentaire sont difficiles à entreprendre sur les grands cours d'eau. Aussi peuton mettre en ouvre une méthode alternative dite "approche morphologique », qui postule que le déplacement des matériaux entraîne des modifications de la morphologie du chenal; par conséquent la mesure de ces modifications peut être utilisée pour estimer le transport de la charge solide. Deux exemples sont présentés : celui de la Moselle, où l'objectif était d'évaluer l'équilibre dynamique de la rivière d'amont en aval, en comparant trois sites et la rivière Beni en Amazonie bolivienne, où l'on cherchait à caractériser l'efficacité morphogénique des écoulements sur un méandre. À partir de relevés bathymétriques et topographiques sont élaborás des modèles numériques de terrain (MNT). Sur la Moselle, les résultats montrent une substitution de la charge solide et sa redistribution sur chaque site; une différence importante entre les sites étudiés est également mise en évidence, cer- 
tains montrant les marques d'un nouvel équilibre dynamique (fig. 5). Sur la rivière Beni, les MNT révèlent une très forte variabilité interannuelle des volumes érodés et déposés, qui semble être liée à la durée des écoulements liquides (fig. 6). Enfin, la vitesse de transit sédimentaire a été évaluée sur les rivières de l'Ardenne belge grâce aux scories métalliques (fig. 7). On montre ainsi l'affinement granulométrique des particules transportées par les rivières d'amont en aval et une vitesse moyenne de progression des éléments les plus grossiers de l'ordre de 3,3 à 3,9 km par siècle.

\section{Introduction}

Floodplains are complex assemblages of landscapes composed of active landforms (such as channels) and ancient stabilized units of various ages and origins (mainly abandoned channels, former islands and banks). Floodplains are thus exceptional sites of palaeoclimatic and historical archives, recordinglong - and short - term hydro-climatic evolution and human activities (land use, engineering works) affecting the valley and catchment .

The periodicity of inundation of an active floodplain is a matter requiring definitions. According to L. B. Leopold and M. G. Wolman (1957), and L. B. Leopold et al. (1964) an active floodplain is regularly flooded (every year or every 1.5 year). J. Alexander and S. B. Marriott (1999) have proposed a definition of active floodplain adapted to the great diversity of hydrologic functioning: 'The active floodplain is a relatively flat area adjacent to a stream that is periodically (over a period of $100-200$ years) inundated by flood water, at least part of which emanates from the channel'. In the same way, a 'genetic floodplain' corresponds to the recent overbank deposits (Nanson and Croke, 1992).

The regeneration of a floodplain is controlled by interrelations with the active channel: the lateral migration of an active channel or the creation of a new channel (by avulsion) induces the local destruction of a floodplain, whereas the floodplain construction is mainly associated with overbank deposits, progressive sedimentation in channels, or rapid migration of the active bed (meander cut-off). Thus, attempts of classification are based on the relations that exist between the fluvial pattern and floodplain sedimentary units (Brierley, 1991; Leopold and Wolman, 1957; Lewin, 1978; Miall, 1996; Nanson and Croke, 1992). G. J. Brierley and E. J. Hickin (1991) show that a range of floodplain types exists, which do not directly correspond to channel planform patterns. Another mean of interpretation uses the textural features of floodplain sediments. A number of field studies have focused on grain size distributions, which can help to determine spatial variability in response to the dynamic behaviour of sediment transport and deposition (Bravard and Peiry, 1999; Brown, 1985; James 1985; Passega, 1957; Pizzuto, 1987; Walling et al., 1997; Warner, 1992; Marriott, 1996).

The main difficulty lies in the precise quantification of erosion - sedimentation rates in active channels and their associated floodplain, factors that are controlled by different processes and evolve at different time scales. Periods of sediment transport in channels are interspersed by longer periods of sediment storage in the bed and bars. The residence time of sediment is much longer in floodplains, where deposition rate depends on the concentration of suspended sediment in water, and on frequency and duration of overbank flows, density of vegetation and topography.

The objective of this paper is to focus on multi-disciplinary approaches developed on diverse active floodplains to evaluate interactions between active channel and floodplain, deposition and erosion rates and their spatial and temporal heterogeneity. The recent advances are based on various new field methods and equipments. The case studies presented here concern American and European rivers, in diverse environmental contexts and that are unequally affected by human impact. The selected rivers are analysed in a systemic way, with regards to external factors controlling fluvial dynamics, mainly hydrologic functioning (water discharge variation in the case of the Beni River, Bolivian Amazonia, and impact of a large flood in the case of the Rhône River, France) and anthropogenic influence (Loire and Moselle Rivers, France and rivers of Belgian Ardenne). These case studies underline the need for coupling methods that highlight floodplain evolution at different time scales and spatial scales. They also emphasize the usefulness of detailed investigations conducted in the field to further understand dynamic evolution of active floodplains.

\section{Historical rate and pattern of floodplain construction}

\section{'Recycling time' of floodplains}

Historical analysis is an important means to study floodplains (Gurnell et al., 2003; Hooke, 1995; Petts et al., 1989) with two main objectives: i) evaluation of spatial and temporal variation of fluvial forms and ii) determination of anthropogenic impacts on fluvial landforms, such as engineering works (embankment, dams) and land uses. Recently, the development of GIS for fluvial system study helped to perform morphodynamic analyses and enabled to calculate the 'recycling time' of a floodplain at historical or annual time scale. Areas of erosion and deposition may be obtained by mapping the active channel change on aerial photographs and satellite images; in this way it is possible to calculate the rate of destruction and construction of floodplains. On this basis, L. Mertes et al. (1996) calculated a 'recycling time' for the anastomosed Solimões-Amazon floodplain (Peru Brazil) ranging from 1000 years in the middle valley to 2000 years downstream, and this recycling time may exceed 4000 years near Obidos. Using the same method, the recycling time of two meandering rivers of the upper Amazonian lowlands was calculated: the Manu River in Peru (Salo et al., 1986) and the Beni River in Bolivia (fig. 1; tab. 1). The two tributaries rework between 1.0 and $2.5 \%$ of the area of their floodplain each year, suggesting a recycling time of 40-100 years, i.e. an order of magnitude higher than on the middle and lower valley of the main river. In the case of the 


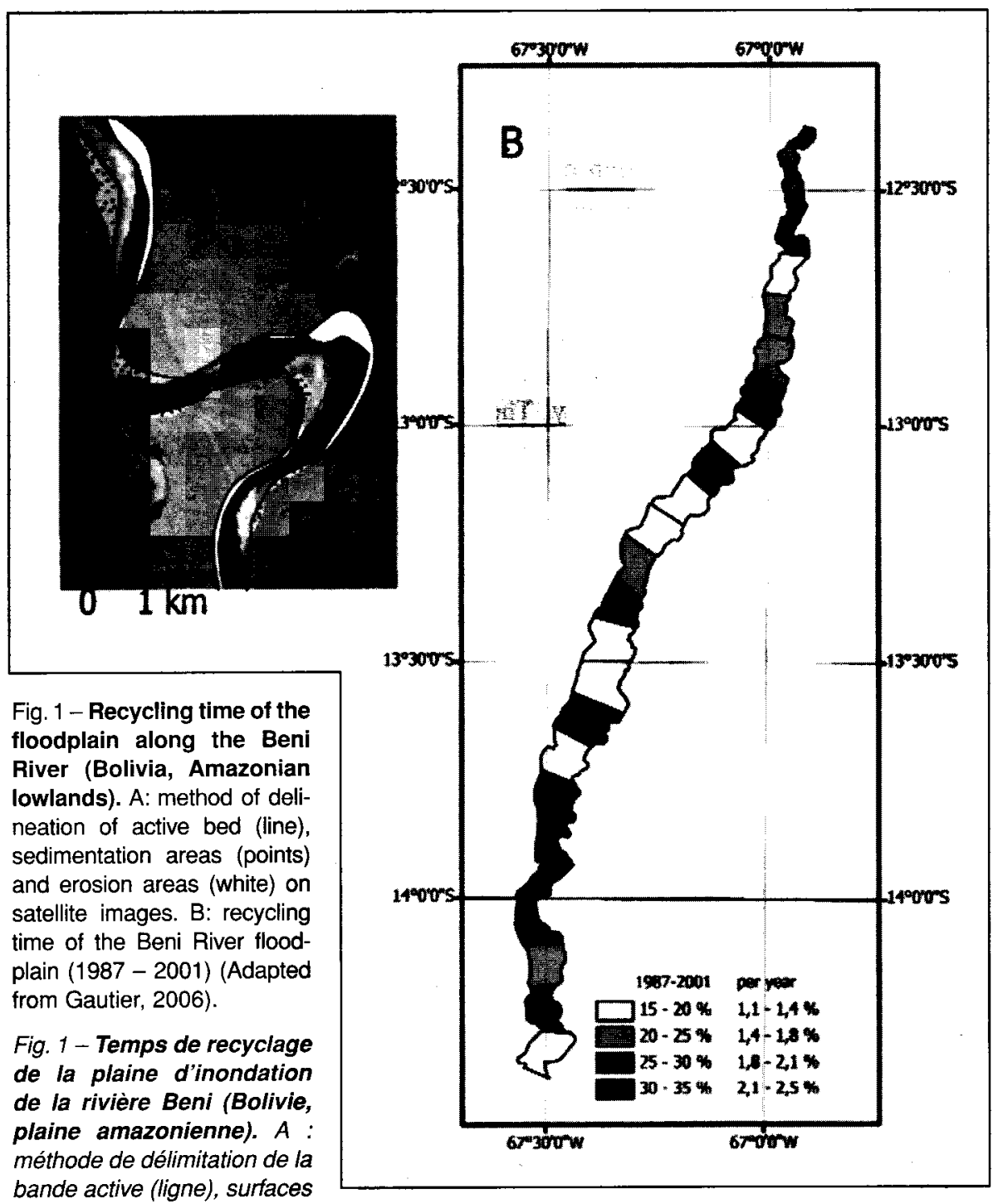

bande active (ligne), surfaces de sédimentation (points) et

surfaces d'érosion (blanc) sur les images satellites. $B$ : temps de recyclage de la plaine d'inondation de la rivière Beni (1987 - 2001) (d'après E. Gautier, 2006).

Beni River, the annual recycling time varies greatly in relation to the duration of the discharge exceeding the bankfull level (Gautier et al., 2007).

This approach is limited by different factors. The first one is the availability of documentation with a sufficiently high resolution to reconstitute the floodplain history for a long period, and to determine long-term average tendencies. Historical maps that allow a diachronic analysis since the 19th century, are available in the Old World, but their accuracy can be questioned (Gurnell et al., 2003). In the 20th century, before Landsat images, Corona declassified images (19591972 , with a resolution up to $1.8 \mathrm{~m}$ ) and aerial photographs provide information on countries where maps and aerial pictures are rarely available. However, the method based on the quantification of erosion and deposition areas is efficient for evaluating specific fluvial patterns and dynamics: measurement of sediment exchanges at a meso-scale is possible on rivers where lateral mobility is predominant (meandering and braided rivers). This approach, however, is not suitable for floodplains of anastomosed rivers characterized by ver- tical aggradation and fluvial form change of low intensity.

\section{Linking floodplain deposition and channel mobility at different time scales}

Aerial photographs, satellite images and maps provide information on the planform evolution of floodplains at a pluri-decadal timescale; data on vertical evolution are much more rarely available. Precise topographic and bathymetric surveys may be realized in the active channel and plain (generally for navigation or engineering works), but they do not usually cover the entire floodplain and they are rarely re-surveyed. In the case of the Loire River, several floodplain crosssections were measured in 1970 and 1995 by the Loire Basin Water Survey; we re-surveyed these cross-sections in 2004 with a RTK DGPS coupled with a total station (fig. 2, tab. 1). These cross-sections are used to determine erosion and sedimentation rates for a pluri-decadal period, on each unit of the floodplain: active and abandoned channels, bars, islands and lateral margins. In the middle Loire River, comparison of cross-sections shows a high variability in erosion and sedimentation rates. Since the 1970 's, the river experienced a significant incision of the active channels (at a mean rate of $50 \mathrm{~mm}$ per year). A rapid vertical accretion (mean annual rate of $50 \mathrm{~mm}$ ) was also observed on two types of landforms, namely on young islands corresponding to former bars that evolved to vegetated islands (cross-section a, on fig. 2), and on banks characterized by thick deposits (see cross-section b). Lower rates of sedimentation were measured on ancient islands (i.e. formed before 1970, see crosssection $b$ ). These older islands constitute complex fluvial forms, due to their longevity; their development is mainly associated with lateral aggradation on the island banks. On distal parts of the floodplain, sedimentation is more reduced. These contrasted erosion - sedimentation rates reflect the topographic and sedimentary readjustment of the river to socio-economic and hydrologic changes of the Loire River since the 19th century, including engineering works, lack of high floods, and massive gravel extraction in the fluvial bed (Gautier, 2006; Gautier and Grivel, 2006; Gautier et al., 2007). The results are important for river managers whose objective is to limit or to stop fluvial bed entrenchment and to improve sediment entrainment between deposition areas 


\begin{tabular}{|c|c|c|c|c|}
\hline 1. Time considered & 2. Problem addressed & $\begin{array}{c}\text { 3. Source } \\
\text { (data and spatial resolution) }\end{array}$ & 4. Methods & 5. River case study \\
\hline $\begin{array}{l}\text { Long-time scale } \\
\text { (Pluri-centennal) }\end{array}$ & $\begin{array}{l}\text { Floodplain sedimentation } \\
\text { rate } \\
\text { Floodplain recycling time } \\
\text { Lateral and longitudinal } \\
\text { migration of sediment }\end{array}$ & $\begin{array}{l}\text { Specific element present in } \\
\text { sediment: } \\
\text { ironwaste product }\end{array}$ & $\begin{array}{l}\text { Coring and slag } \\
\text { concentration } \\
\text { measurement } \\
\text { Size of slag elements } \\
\text { along rivers }\end{array}$ & $\begin{array}{l}\text { Belgian Ardenne rivers : } \\
\text { Sedimentation rate of } \\
\text { floodplains, lateral mobility } \\
\text { of rivers, flooded areas } \\
\text { since the Middle Age } \\
\text { Bedload progression speed, } \\
\text { river competence }\end{array}$ \\
\hline $\begin{array}{l}\text { Intermediate time- } \\
\text { scale } \\
\text { (Pluri-decadal to } \\
\text { pluri-annual) }\end{array}$ & $\begin{array}{l}\text { Floodplain recycling time } \\
\text { Erosion - sedimentation } \\
\text { rate } \\
\text { Human impact }\end{array}$ & $\begin{array}{l}\text { Remotely sensed imagery: } \\
\text { Corona photos }(1960 \mathrm{~s} ; 2 \mathrm{~m}) \\
\text { Landsat images (>1980 s; } \\
15-30 \mathrm{~m}) \\
\text { Field survey: } \\
\text { topographic and bathymetric } \\
\text { measurements (>1970 s; } \\
<0.50 \mathrm{~m})\end{array}$ & $\begin{array}{l}\text { Planform evolution: } \\
\text { calculation of erosion and } \\
\text { deposition areas, } \\
\text { migration of active bend } \\
\text { Integration in GIS } \\
\text { Cross-sectional forms, } \\
\text { longitudinal profiles: } \\
\text { calculation of erosion and } \\
\text { sedimentation rate per } \\
\text { fluvial unit } \\
\text { Integration in GIS }\end{array}$ & $\begin{array}{l}\text { Beni River (Bolivian } \\
\text { Amazonia) } \\
\text { Regeneration of floodplain, } \\
\text { meander dynamics } \\
\text { Loire and Moselle Rivers } \\
\text { (France): impact of gravel } \\
\text { extraction and engineering } \\
\text { works }\end{array}$ \\
\hline $\begin{array}{l}\text { Short-time scale } \\
\text { (annual and specific } \\
\text { event) }\end{array}$ & $\begin{array}{l}\text { Sediment movement in } \\
\text { active channels } \\
\text { Sediment exchange } \\
\text { between floodplain and } \\
\text { active channel } \\
\text { Efficiency of water and } \\
\text { sediment discharge }\end{array}$ & $\begin{array}{l}\text { Field survey: } \\
\text { topographic and bathymetric } \\
\text { measurements }(<0.10 \mathrm{~m}) \\
\text { Sediment facies } \\
\text { characterization } \\
\\
\text { Remotely sensed imagery: } \\
\text { Spot image }(2003,10 \mathrm{~m}) \text {, } \\
\text { Field survey : forms and } \\
\text { sediment characterization }\end{array}$ & $\begin{array}{l}\text { Flooded areas, sediment- } \\
\text { body geometry, sediment- } \\
\text { facies characterization }\end{array}$ & $\begin{array}{l}\text { Beni River: evolution of a } \\
\text { meander, influence of } \\
\text { external factors (water and } \\
\text { sediment discharge) } \\
\text { Moselle River: readjustment } \\
\text { to gravel extraction, } \\
\text { longitudinal variation of } \\
\text { sediment budget } \\
\text { Rhône River (France): } \\
\text { impact of November - } \\
\text { December } 2003 \text { flood }\end{array}$ \\
\hline
\end{tabular}

Table 1 - Synthesis of objectives, data and methods

Tableau 1 - Synthèse des objectifs, données et méthodes.

Fig. 2 - Evolution of floodplain along the middle Loire River sector (France) since the $1970 \mathrm{~s}$ - with example at two cross-sections. A: Bec d'Allier site; B: Pouilly-sur-Loire site.

Fig. 2 - Évolution de la plaine d'inondation de la Loire moyenne (France) depuis les années 1970 exemple de deux profils transversaux. $A$ : site $d u$ Bec d'Allier ; $B$ : site de Pouilly-sur-Loire.
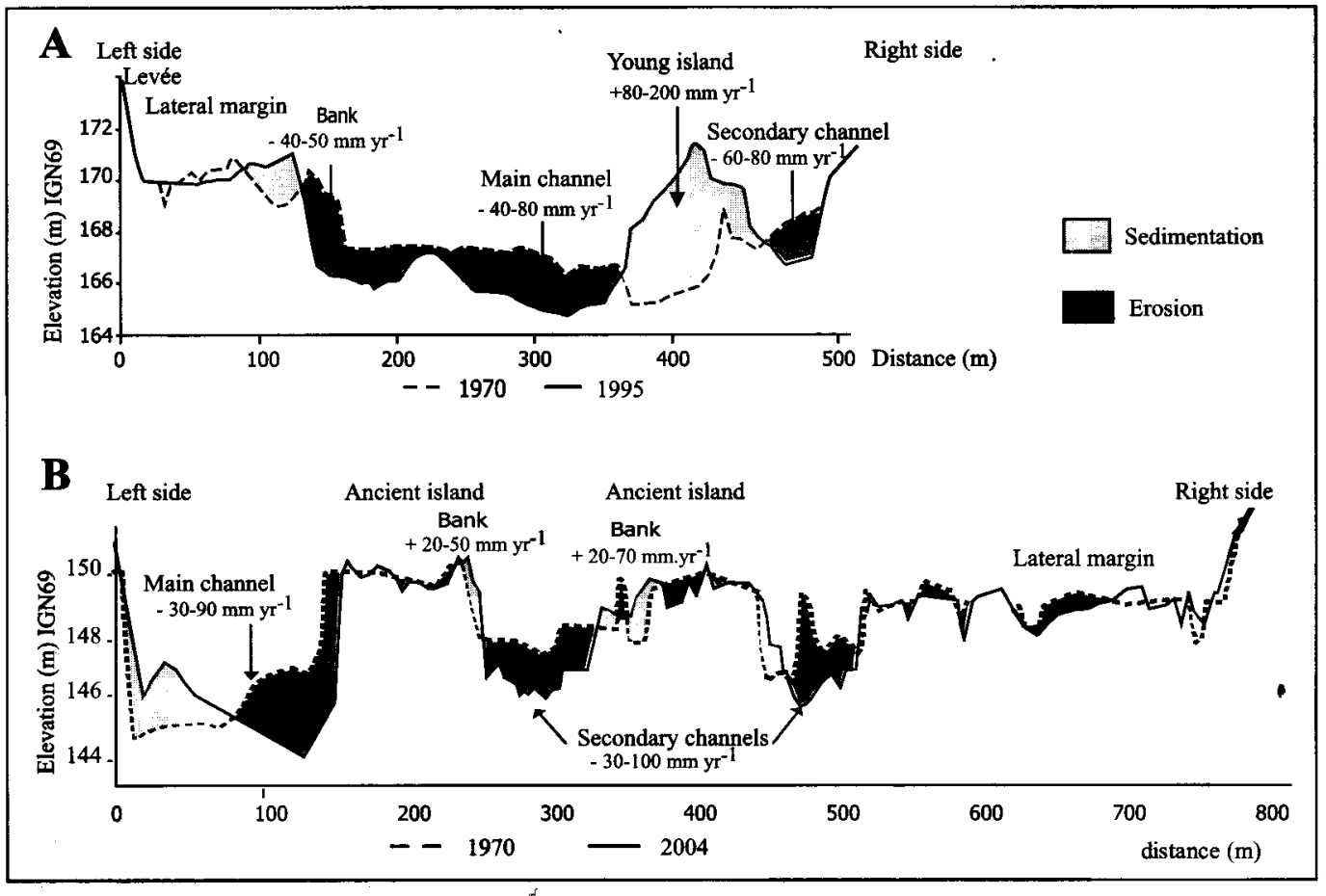
(mainly young islands and banks in the case of the middle Loire River) and active channels.

In France, recent and rapid incision of the fluvial bed is observed in numerous rivers, like the Loire or the Moselle rivers and represents an important issue in terms of water resource, infrastructure stability (bridges, dykes...), and ecology of aquatic and wetlands biotopes (Bravard, 1994; Bravard et al., 1997). For this reason, considerable attention has been paid to the vertical stability of river beds. On a longitudinal profile of the Moselle River, for example, it can be seen that the upper section underwent important destabilization caused by coupled effects of gravel bed extractions and artificial meander cut-offs (fig. 3; tab. 1).

Longitudinal profiles and cross-sections are especially adapted to pluri-annual studies, and they provide precise data about vertical evolution of the fluvial bed (tab. 1). However, their application is limited by numerous difficulties: $i)$ the need to locate the survey exactly at the same place, which is relatively easy nowadays with a GPS, but the difficulty to relocate the 'old' surveys remains; ii) in situ measurement needs time and effort, especially in densely vegetated areas where vegetation must be cleared before the survey. Furthermore, one cannot extrapolate the data across the entire fluvial unit, because of variable deposition and erosion rates.

Recent advances in documenting historical rates and pattern of floodplain sedimentation have included the use of metal mining-sediments (Lewin and Macklin, 1987), ironwork waste products present in sediments (Houbrechts and
Petit, 2006), or fall-out radionuclides ${ }^{137} \mathrm{Cs}$ and ${ }^{210} \mathrm{~Pb}$ (He and Walling, 1996; Walling and He, 1998; Steiger et al., 2001; Stokes and Walling, 2003). In Ardenne rivers in Belgium, historical floodplain sedimentation has been evaluated using slag elements (Sluse and Petit, 1998; Houbrechts and Petit, 2003). These ironwork waste products come from hundreds of blast furnaces and bloomeries built close to rivers between the 14th and the 19th centuries. Slag was piled onto the floodplains and frequently thrown out directly into rivers. For centuries, slag elements were carried away during floods and spread out along rivers. Slag particles are easily recognisable, due to their visual characteristics. They are vitreous and of distinct colours, such as blue or green. Different kinds of slag were produced in ironworks (Houbrechts and Weber, 2007), and most frequently in blast furnaces.

The rate of floodplain formation in Ardenne valleys was first estimated using microscopic slag as a stratigraphical marker by J. Henrottay (1973). Several floodplains of the Ourthe basin and the Meuse River downstream from Liège have been investigated. Since then, complementary observations have been undertaken in the Ourthe basin and a new methodology for slag concentration measures has been defined (Houbrechts, 2005; Houbrechts and Petit, 2006). In these rivers, the thickness of deposits with slag generally exceeds $1 \mathrm{~m}$, which indicates a rate of accumulation of 15$20 \mathrm{~cm}$ per century. Everywhere the thickness of silt deposited since the 14th century is greater than the layer of

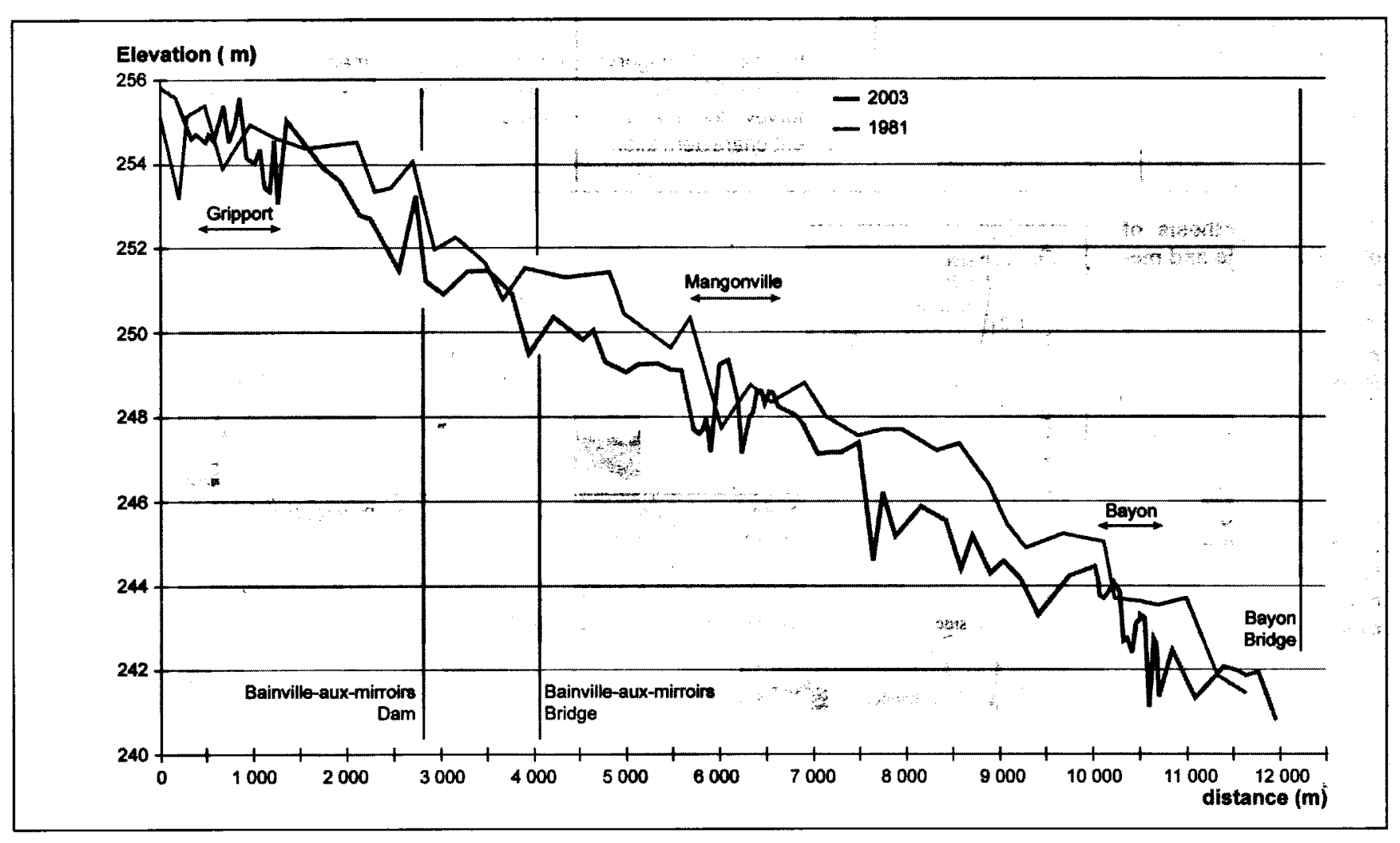

Fig. 3 - Evolution of the longitudinal profile of the Moselle River sector (France) between Gripport and Bayon (1981 - 2003).

Fig. 3 - Évolution du profil en long de la Moselle (France) entre Gripport et Bayon (1981 - 2003). 
old silt deposited prior to slag deposition. Human activities (deforestation, agricultural practices and extension of the area under tillage) have probably played a dominant role in silt accumulations in the valleys. P. Sluse and F. Petit (1998) have also used slag to study floodplain evolution south of the Ardenne. Sedimentation rates there are slightly lower than to the north of the Ardenne. Two explanations for this difference are proposed. Deforestation in south Ardenne catchments has been less important, and land use of these watersheds is now dominated by forests and pastures, such that soil erosion is lower than in the northern part of the Ardenne. Furthermore, loess deposits are thinner in the southern Ardenne and thus, there is less material to erode.

When slag elements are directly in contact with gravel deposits, it means that the river moved laterally since inception of the iron industry, swept away older sediments and deposited more recent sediments contaminated by slag. Coring carried out along perpendicular cross-sections has allowed estimations of the extent of lateral displacements of the channel since about the Middle Age. Therefore, this method also provides information concerning the recycling time of floodplain and the delimitation of the 'space of functional lateral mobility' as defined by the SDAGE Rhône-Méditerranée-Corse (Malavoi, 1998). Lateral erosion rates defined by this method may be underestimated because the river may have crossed the zone where old silt was eroded several times, which may explain low lateral erosion values. The presence of slag elements associated with overbank deposits on low terrace levels can indicate whether these units are flooded or not during extreme events. Consequently, slag can also be used for mapping the extent of flooded areas.

\section{Sediment budget in active channels}

Sediment budget is a significant concept in fluvial geomorphology and varies in objectives and methodology (Reid and Dunne, 2003). The estimation of a sediment budget within the active bed is relevant for at least two main objectives: i) determination of the effect of various forcing factors (mainly water and sediment discharge) on spatial or temporal evolution of fluvial forms, and ii) evaluation of readjustment of the system after an alteration (such as construction of embankment or dam, gravel extractions, etc.). Determination of sediment transfer between active channel and floodplain, and of longitudinal progression of bedload are difficult on large rivers,

Table 2 - Sediment budget (in $\mathrm{m}^{3}$ ) of the Rhône River (France) during the December 2003 flood, including the Arles floodplain and the western part of the delta.

Tableau 2 - Bilan sédimentaire (en $\mathrm{m}^{3}$ ) du Rhône (France) lors de la crue de décembre 2003, comprenant la plaine d'Arles et la partie occidentale du delta. especially during high water levels. For this reason, many studies develop an approach using a combination of direct measurements (water discharge and suspended load) and indirect methods associating planform evolution, bedforms, sediment features and tracing of specific sediment.

\section{Impact of large floods on floodplain and sediment budget}

High floods strongly impact floodplains (see, for example, the impact of the 1993 flood on the Mississippi River; Gomez et al., 1997; Horowitz, 2006, or the effects of a flood on ephemeral streams in Spain, Hooke and Mant, 2000), but assessing their effects is difficult and needs a combination of various equipments and methodologies. In November and December 2003, southern France received exceptional rainfall that generated historical floods, especially in the Rhône basin. As a consequence of intense rainfall, the lower Rhône River, with a peak discharge of $11,500 \mathrm{~m}^{3} \cdot \mathrm{s}^{-1}$ at Beaucaire-Tarascon, inundated $\sim 500 \mathrm{~km}^{2}$ of its alluvial/delta plain and destroyed several dykes. The most damaged zones were located between Beaucaire and Arles, which were flooded by 16,000 to $18,106 \mathrm{~m}^{3}$ of water. Fluvial landforms, sediment-body geometries and sedimentfacies characteristics were determined using a combination of topographic maps, remote sensing data, field measurements and laboratory analyses. In the flood basin and near the channel, 170 samples were collected to reveal both morphological and lithological variations in the subsurface. All data were compiled on topographic maps enlarged to 1:5000 and covered by $1 \mathrm{~m}^{2}$ squares. Finally, a SPOTLIGHT image, supplemented by field survey, was analyzed to define the flooded areas. In this manner, sediment budget was calculated (Arnaud-Fassetta, 2007).

On the left bank of the Rhône River, between BeaucaireTarascon and Arles, the flooded area beyond dykes and strictly linked to the Rhône flood waters was estimated at $22 \mathrm{~km}^{2}$. The flood deposits are fine-grained, essentially composed of silts (tab. 2). Their volume of $25,040 \mathrm{~m}^{3}$ represents only $3 \%$ of the total volume deposited in the floodplain outside dykes. The eroded volume is limited $\left(200 \mathrm{~m}^{3}\right)$. Both in the northern and western parts of the delta, two major breaches were opened in dykes on the right bank of the Petit Rhône River, leading to formation of crevasse

\begin{tabular}{|c|c|c|c|c|c|c|c|c|}
\hline & \multicolumn{6}{|c|}{ Deposited sediment volume } & \multirow{2}{*}{$\begin{array}{c}\text { Eroded } \\
\text { Sediment } \\
\text { volume }\end{array}$} & \multirow{2}{*}{$\begin{array}{l}\text { Sediment } \\
\text { balance }\end{array}$} \\
\hline & $\mathbf{G}$ & CS-MS & FS-VFS & SI & C & Total & & \\
\hline Arles & 0 & 1783 & 6640 & 14,445 & 2172 & $\begin{array}{c}25,040 \\
3 \%\end{array}$ & -200 & \\
\hline $\begin{array}{l}\text { Petit } \\
\text { Argence }\end{array}$ & 699 & 249,280 & 132,796 & 77,016 & 9744 & $\begin{array}{c}469,535 \\
58 \%\end{array}$ & $-113,804$ & \\
\hline Claire Farine & 0 & 76,567 & 37,677 & 39,816 & 6247 & $\begin{array}{c}160,307 \\
20 \%\end{array}$ & $-22,198$ & \\
\hline Other sites & 0 & 3829 & 35,760 & 97,763 & 18,195 & $\begin{array}{c}155,547 \\
19 \%\end{array}$ & 0 & \\
\hline Total & $\begin{array}{l}699 \\
0.1 \%\end{array}$ & $\begin{array}{c}331,459 \\
41 \%\end{array}$ & $\begin{array}{c}212,873 \\
26 \%\end{array}$ & $\begin{array}{c}229,040 \\
28 \%\end{array}$ & $\begin{array}{c}36,358 \\
4 \%\end{array}$ & 810,429 & $-136,202$ & 674,227 \\
\hline
\end{tabular}




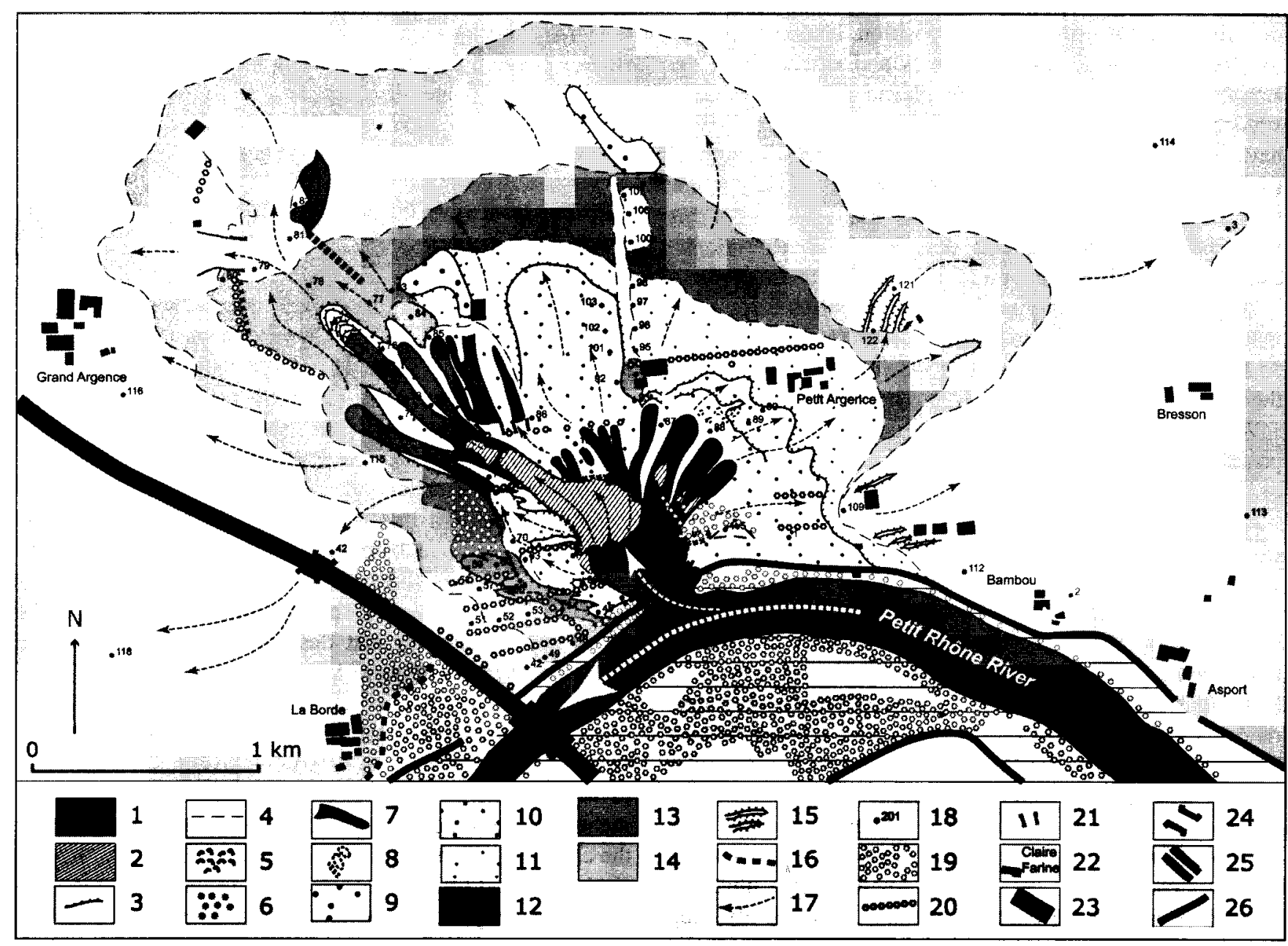

Fig. 4 - Example of high-resolution mapping of the December 2003 crevasse splay (DRL) of Petit Argence (western part of Rhône Delta, right bank of Petit Rhône River). 1: Petit Rhône channel and head of main crevasse channel; 2: floodplain stripping; 3: scarp; 4: gradual boundary; 5 : peat blocks; 6 : fluvial shells (Corbicula fluminea) deposited upstream of breach axis; 7: crevasse channel; 8: erosion cavity; 9: lobe of crevasse splay at DRL (coarse sand + gravel near the breach); 10: lobe of crevasse splay (medium sand); 11: lobe of crevasse splay (fine and very fine sand); 12: lobe of crevasse splay (silty sand); 13: proximal flood basin (sandy silt); 14: distal flood basin (coarse silt); 15: hydraulic dune; 16: flooding-area boundary; 17: direction of flood flows; 18: sampler number; 19: riparian forest and grove; 20: hedge (cypress, poplar); 21: hedge breached by flood flows; 22: permanent settlement ("mas") and outbuilding; 23: raised road; 24: tunnel; 25: bridge; 26: Rhône dyke.

Fig. 4 - Exemple de cartographie haute résolution du delta de rupture de levée (DRL) de Petit Argence (partie occidentale de la plaine deltaique rhodanienne, rive droite du Petit Rhône) lors de la crue de décembre 2003. 1 : chenal du Petit Rhône et racine du chenal principal de $D R L ; 2:$ zone de décapage superficiel de la plaine d'inondation ; $3:$ talus ; 4 :contact graduel ; $5:$ blocs de tourbe ; $6:$ coquilles de faune fluviatile (Corbicula fluminea) déposées en amont de l'axe de la brèche; 7 :chenaux de DRL; $8:$ cuvette d'érosion; $9:$ lobe de DRL constitué de sables grossiers (+ graviers abondant surtout à proximité de la brèche); 10 : lobe de DRL constitué de sables moyens ; 11 : lobe de DRL constitué de sables fins à très fins ; 12 : lobe de DRL limono-sableux ; 13 : épandage sablo-limoneux dans bassin d'inondation proximal ; 14 : épandage de limons grossiers dans bassin d'inondation distal ; 15 : dune hydraulique isolée ; 16 : limite de l'inondation ; 17 : direction des écoulements de crue ; 18 : numéro d'échantillon; 19 :ripisylve et bosquet; 20 : haie d'arbres (cyprès, peuplier) ; $21:$ trouée dans les haies d'arbres par les flux de crue ; 22 : habitat permanent (mas) et dépendances ; 23 ; remblai autoroutier ; 24 : tunnel ; 25 : pont ; 26 : digue du Rhône.

splays and flooding of $414 \mathrm{~km}^{2}$. In the sector of Petit Argence's 'mas' (traditional houses; fig. 4 and tab. 2), the sediment volume was estimated at $469,535 \mathrm{~m}^{3}$ (with $81 \%$ sand), for an eroded volume of $113,804 \mathrm{~m}^{3}$ : the sediment budget is widely positive $\left(355,731 \mathrm{~m}^{3}\right)$. In the sector of Claire Farine's 'mas', deposition is lower than at Petit Argence (tab. 2), and the sediment budget is also positive. Downstream of Sylvéréal, sediments accumulated in the sectors not directly influenced by crevasse splays represent a volume of $155,547 \mathrm{~m}^{3}$ (with $63 \%$ silt).
Sediment yielded by crevasse channels in the floodplain has enabled us to determine the sediment load transported by the Rhône channel (texture of splay deposits is similar to bed load and channel deposits); the sand fraction is dominant. Sand deposition on the delta by crevasse splays generates a sediment deficit in the main channel of the Petit Rhône River and eventually at the river mouth. Therefore, a positive sediment budget of the delta plain has negative impacts on sand beaches of the deltaic fringe, which are characterized by a sediment deficit (Sabatier, 2001). The flood 


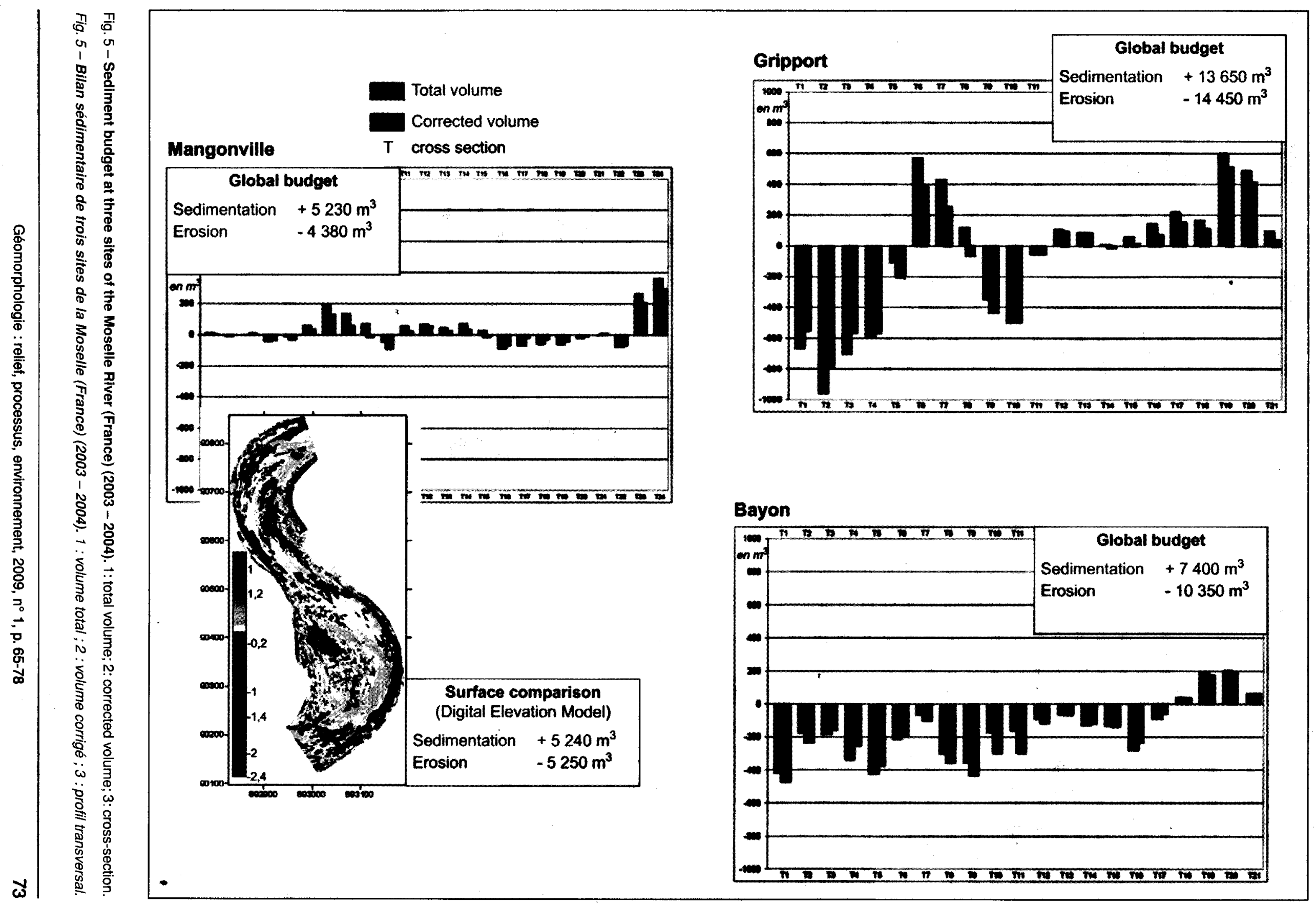


of December 2003 deposited $810,429 \mathrm{~m}^{3}$ of sediments on the delta plain, but $544,332 \mathrm{~m}^{3}$ of sand were transported towards the deltaic coast.

\section{Active channel mobility}

Processes controlling the lateral and vertical mobility of active channels can be analysed by the morphological method, and through the elaboration of digital elevation models (DEM) that help to determine sediment movement (Eaton and Lapointe, 2001; Fuller et al., 2003; Hooke and Mant, 2000; Legleiter and Kyriakidis, 2008; Martin and Church, 1995). The use of precise topographic and bathymetric equipment (Differential Global Positioning System, automatic total station, echosounding system associated with GPS, or Acoustic Doppler Current Profiler) has fostered research on fluvial systems and its progress during the past ten years. In the field, a dense lattice of topographic and bathymetric points (and/or cross-sections) is recorded on watered and dewatered areas, before and after hydrological events; different water levels (mainly bankfull and flood level) are also registered. After kriging, DEMs are elaborated and comparing them allows us to compute the sediment budget of the study zone.

On the Moselle River, the objective has been to evaluate the readjustment of the river to gravel extraction, more than twenty years after it ended. Three different sections were selected from the upper to lower valley (fig. 3 and fig. 5). Two main results are observed: i) the sediment load substitution and its redistribution at every site, and ii) the important variation between the three selected sites during the study year (2003-2004) (Beck and Corbonnois, 2003 and 2004). At the upper site (Gripport), remobilisation of the sediment load was three times higher than at the middle and lower valley sites. That sedimentation exceeds erosion and enables the reconstruction of the alluvial bed. At the site located in the middle valley (Mangonville), a relative stability was noticed, with an eroded volume that equals sedimentation. Downstream (Bayon), erosion is still dominant because of sediment deficiency due to gravel extraction. However, this result suggests river-bed re-equilibrium after a long period (50 years) of destabilization.

Based on the same method, a study on the Beni River (Bolivian Amazonia) was conducted to better understand the dynamics of a tropical meandering river and, more precisely to quantify the erosion and deposition areas at an annual scale, with regards to variability of water and sediment discharge. Following a meso-scale approach based on satellite images, a meander loop was selected. On the basis of bathymetric, topographic and sediment surveys, annual DEMs were constructed; they provide information on sediment movement along the entire meander and on fine-scale deformation of the meander (fig. 6). Two inter-annual evolutions presented on fig. 6 highlight the marked variability in erosion and sedimentation throughout the meander. The first year (2002 - 2003, fig. 6a) is characterized by a negative sediment budget: the channel was subject to general erosion, with maximal values in the downstream zone. On the point bar, erosion occurred mainly upstream in the outer part of the bar, whereas accretion was maximal on the inner zone, on the apex, and downstream. This negative sediment budget can be associated with a relatively long duration of the discharge higher than bankfull level ( 9 days) and an important sediment

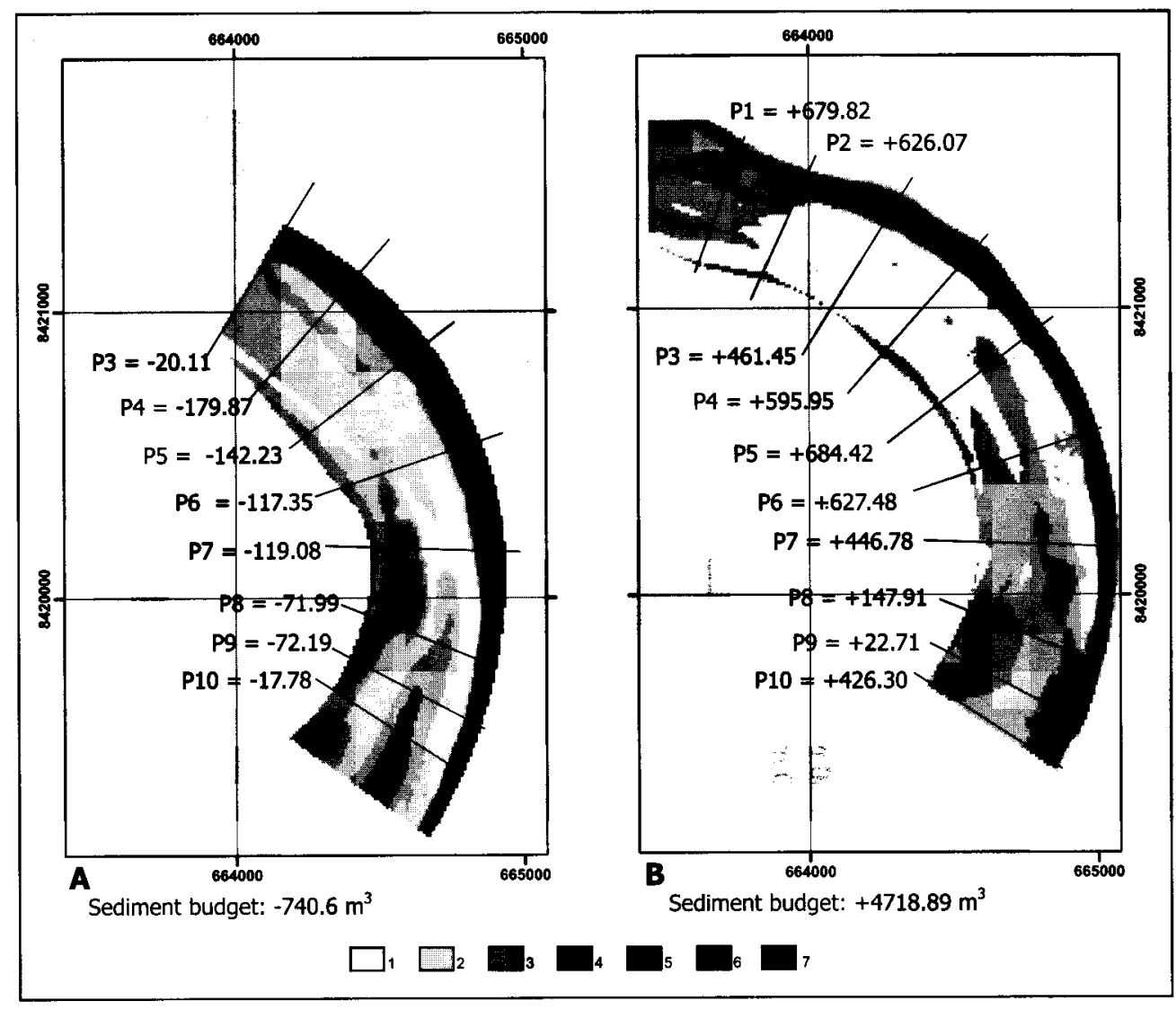

Fig. 6 - Sediment budget at a meander loop of the Beni River in Amazonian lowlands. A: 2002 2003; B: $2004-2005$. Digital elevation models (1:6 - $8 \mathrm{~m} ; 2: 6-2.5 \mathrm{~m} ; 3: 2.5-1 \mathrm{~m} ; 4: 1$ - $0 \mathrm{~m} ; 5: 0$ $-1 \mathrm{~m} ; 6:-1--2.5 \mathrm{~m} ; 7:-2.5--8 \mathrm{~m}$ ) and sediment budget at cross-sections (in $\mathrm{m}^{3}$ ).

Fig. 6 - Bilan sédimentaire d'une boucle de méandre de la rivière Beni dans la plaine amazonienne. $A: 2002-2003 ; B: 2004-2005$. Modèles Numériques de terrain $(1: 6-8 \mathrm{~m} ; 2: 6-2.5 \mathrm{~m}$; $3: 2.5-1 \mathrm{~m} ; 4: 1-0 \mathrm{~m} ; 5: 0--1 \mathrm{~m} ; 6:-1--2.5 \mathrm{~m} ; 7:-2.5--8 \mathrm{~m})$ et bilan sédimentaire sur les profils transversaux (en $\mathrm{m}^{3}$ ). 
load varying between thirty tonnes per second and seventy tonnes during the flood period. In contrast the meander was affected by an important deposition during the 2004-2005 period (Fig. 6b). The accumulation -on the point bar was twice that of the previous inter-annual evolution. Accretion reached 6-7 metres in the second half of the point bar, and this created a scroll bar topography and a lateral deformation of the meander. This important sedimentation phase is associated with a weak hydrology: the year was dry and no flood occurred and only one day of discharge exceeding the bankfull level was recorded. The sediment load was low, with maxima varying between 20 and 35 tonnes per second, but the mean suspended concentration exceeded by $16 \%$ the value of the $2002-2003$ period. Thus, this study shows the inverse correlation between deposition on the meander and water discharge: a long duration of discharge higher than the bankfull level induces a predominant erosion of the meander.

Even if the DEM provides less precise quantification of the local sedimentation-erosion rate than topographic surveys realized with a total station, analysis of planform adjustment and estimation of the remobilized volume of sediment are more reliable. Furthermore, DEMs are particularly adapted for comparison of the morphogenic effect of different hydrologic events on fluvial forms (like the meander of the Beni River) or for evaluating the longitudinal variation of the impact of the same hydrologic events (as on the different Moselle sites).

\section{Bedload progression in the fluvial bed}

Different methods are used to evaluate bedload entrainment and its travel length: active (radio) tracers and passive tracers (iron, magnetic), and colorimetric markers (Billi, 1988; Ergenzinger et al., 1989; Ferguson et al., 2002; Schmidt and Ergenzinger, 1992). These methods however document bedload progression at a relatively short time scale, and it is difficult to extrapolate results for a longer period.

Bedload progression has been evaluated in Ardenne rivers using slag elements (Sluse and Petit, 1998; Houbrechts and Petit, 2003). The size of slag elements was studied along eighteen rivers of different size and properties. These data serve to determine the effective competence of these rivers, to analyse the hydraulic sorting downstream of metallurgic sites, and to evaluate bedload progression speed. Figure 7 shows the trend of the size of the 10 largest particles measured by the b-axis (corresponding to the $D_{95}$ ) using a cumulative distance from the closest iron factory along the Rulles river course (site 1). Slag elements brought down by tributaries shed light on the increase in the slag size in the Rulles (sites 6 and 11). Downstream of input sites, we systematically observe a rough decrease in particle size, which decreases approximately to $20 \mathrm{~mm}$ in diameter in less than $5 \mathrm{~km}$ (sites $2-3 ; 7-9 ; 12-14$ ). This decrease does not result from modification in hydraulic characteristics of the river nor from a diminution of its competence, since the unit stream power remains constant along its course (25$30 \mathrm{~W} / \mathrm{m}^{2}$ at the bankfull discharge).

Downstream, the slag size remains almost constant whatever the distance. It represents the effective competence of the river (the particle size transported along substantial distances and evacuated out of the catchment). The particle size $(15-20 \mathrm{~mm})$ is relatively small in comparison with observations from other Ardenne rivers. A relationship can be established between the size of slag elements and unit

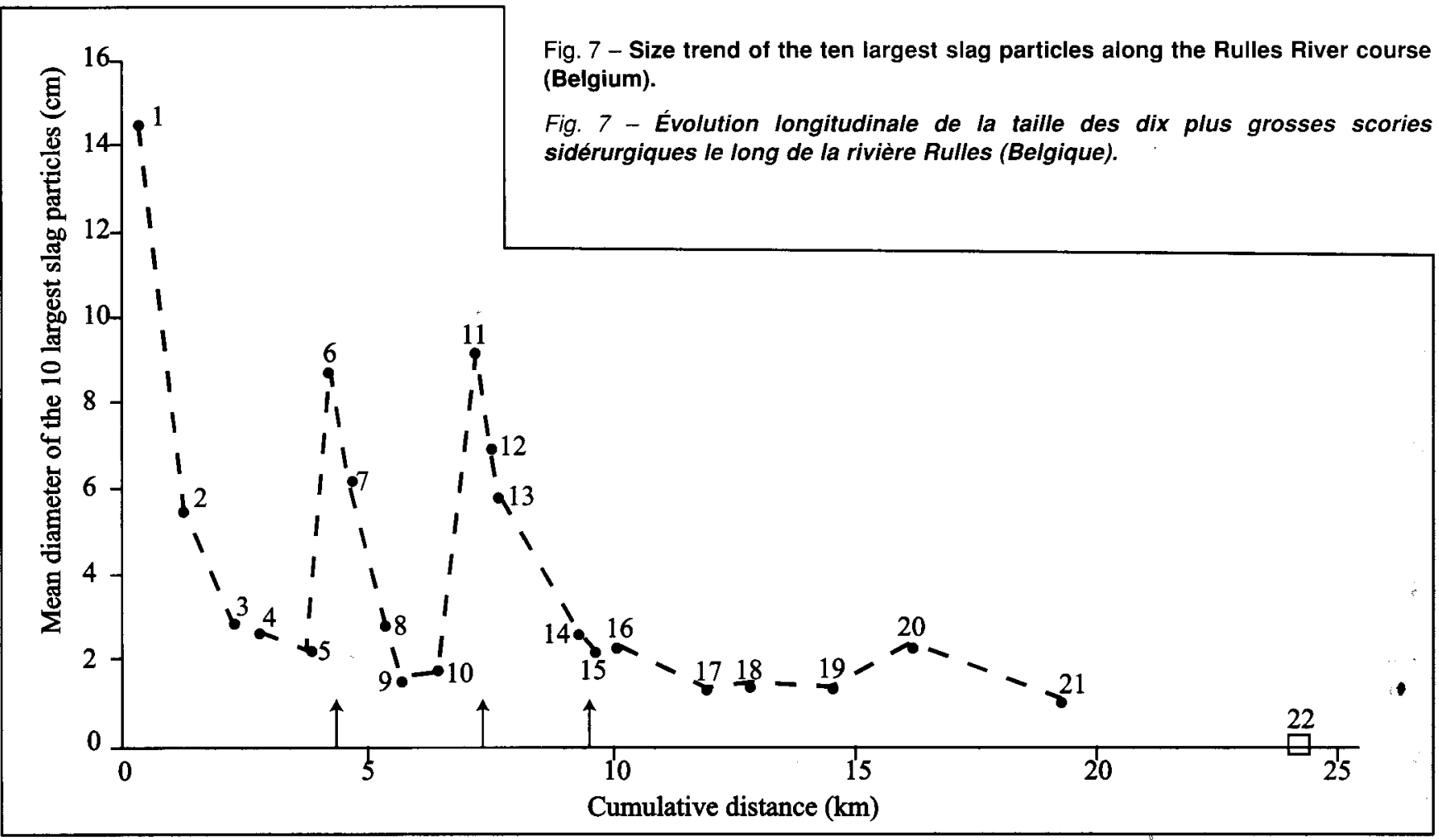


stream power of the rivers where samples were collected (Houbrechts and Petit, 2003). Several slag elements (10$14 \mathrm{~mm}$ in diameter or $9-12 \mathrm{~mm}$ using equivalent diameters) have been found $12.5 \mathrm{~km}$ downstream of the nearest iron factory dated from the mid 17 th century (fig. 7). This implies that the bedload wave progression is at least $3.3 \mathrm{~km}$ per century. The most upstream site in the Semois River, where no slag has been found, shows that the bedload wave progression is less than $17 \mathrm{~km}$ (less than $3.9 \mathrm{~km}$ per century). A similar progression has been observed in the Ourthe River (between 1.8 an $2.3 \mathrm{~km}$ per century). These values are low in comparison with others studies (between 10 and $20 \mathrm{~km}$ per century), but most of them have been obtained in mountain rivers with stronger energy (Tricart and Vogt, 1966; Salvador, 1991).

\section{Conclusion}

This review paper focuses on various methods dedicated to study sediment budget of active floodplains at different temporal and spatial scales (tab. 1). It underlines the important progress realized during the past ten years in terms of sediment exchanges between active channels and floodplain, of longitudinal progression of bedload and more generally, concerning the general sediment budgeting of active floodplains. At a temporal and spatial meso-scale, diachronic analysis of fluvial systems, based on aerial photographs and satellite images, has been reinforced by use of GIS that helps to determine precisely the evolution rate of each functioning reach and, at a finer scale, the readjustment of each type of fluvial landform (active tract, abandoned channels, lateral margins, islands). Specific elements trapped in floodplain deposits (such as iron slag in Ardenne rivers) supplement the approach, documenting remobilization, deposition and erosion rates on floodplains. The main recent advance concerns the fine-scale approach of sediment budget, associated with the elaboration of DEM. Because of the difficulty in measuring sediment movement during floods, especially in large rivers, the morphogical method indirectly provides orders of magnitude of sediment transport and deposition volumes, and information on their spatial and temporal variations. All the presented case studies emphasize two main points: evaluation of efficiency of hydrological events (Rhône and Beni Rivers), and resilience of the fluvial system after a disruption (Moselle and Loire Rivers).

\section{Acknowledgements}

The authors would like to thank J.D. Stanley, J.-C. Thouret and an anonymous reviewer for their useful comments.

\section{References}

Alexander J., Marriott S. B. (1999) - Introduction. In Marriott S. B., Alexander J. (Eds.), Floodplains: interdisciplinary approaches. Geological Society Special Publication 163, 1-13.

Arnaud-Fassetta G. (2007) - L'hydrogéomorphologie fluviale, des hauts bassins montagnards aux plaines côtières: entre géo- graphie des risques, géarchéologie et géosciences. Habilitation à Diriger des Recherches, université Paris-Diderot (Paris 7), 3 vol., 35 p., 435 p. and 357 p.

Beck T., Corbonnois J. (2003) - Les différents états du lit mineur de la Moselle entre Epinal et Méréville, étapes de la reconstruction d'un nouvel équilibre. Actes du colloque le fil de l'eau, Nancy, 10-12 mars 2003, 195-206.

Beck T., Corbonnois J. (2004) - Conditions du transit de la charge solide grossière dans le lit de la Moselle amont. Protocole de mesures et détermination des processus. Actes du colloque Spatialisation et cartographie en hydrologie, Mosella, XXIX/3-4, 341-352.

Billi F. (1988) - A note on cluster bedform behaviour in a gravelbed river. Catena 15, 473-481.

Bravard J.-P. (1994) - L'incision des lits fluviaux : du phénomène morphodynamique naturel et réversible aux impacts irréversibles. Revue de Géographie de Lyon, 69/1, 5-15.

Bravard J.-P., Amoros C., Pautou G., Bornette G., Bournaud M., Creuzé des Chatelliers M., Gilbert J., Peiry J.-L., Perrin J.-F., Tachet H. (1997) - River incision in Southeast France: morphological phenomena and ecological effects. Regulated Rivers: Research and Management 13, 1-16.

Bravard J.-P., Peiry J.-L. (1999) - The CM pattern as a tool for the classification of alluvial suites and floodplains along the river continuum. In Marrott S.B. and Alexander J. (eds.), Floodplains: interdisciplinary approaches. Geological Society Special Publication 163, 259-268.

Brierley GJ. (1991) - Floodplain sedimentology of the Squamish River, Bristish Columbia: relevance of element analysis. Sedimentology 38, 735-750.

Brierley G. J., Hickin E. J. (1991) - Channel planform as a noncontrolling factor in fluvial sedimentology: the case of the Squamish River floodplain, British Columbia. Sedimentary Geology 75, 67-83.

Brown A. G. (1985) - Traditional and multivariate techniques in the interpretation of floodplain sediment grain size variations. Earth Surface Processes and Landforms 10, 281-291.

Eaton B. C., Lapointe M. F. (2001) - Effects of large floods on sediment transport and reach morphology in the cobble-bed Sainte Marguerite River. Geomorphology 40, 291-309.

Ergenzinger P., Schmidt F. H., Busskamp R. (1989) - The Pebble Transmitter System (PETS): first results of a technique for studying coarse material erosion, transport and deposition. Zeitschrift fiir Geomorphologie 33, 503-508.

Ferguson R. I., Bloomer D. J., Hoey T. B., Werritty A. (2002) Mobility of river tracer pebbles over different timescales. Water Resources Research 38, 3.1-3.9.

Fuller I. C., Large A. R. G., Charlton M. E., Heritage G. L., Milan D. J. (2003) - Reach-scale sediment transfers: an evaluation of two morphological budgeting approaches. Earth Surface Processes and Landforms 28, 889-903.

Gautier E. (2006) - Recherches géomorphologiques sur le fonctionnement des plaines d'inondation. Approches croisées de trois grandes plaines. Habilitation à Diriger des Recherches, Université Paris 1, 3 vol., 40 p., 208 p, annexes.

Gautier E., Brunstein D., Vauchel P., Roulet M., Fuertes O., Guyot J.L, Darozzes J., Bourrel L. (2007) - Temporal relations between meander deformation, water discharge and 
sediment fluxes, the Rio Beni floodplain (Bolivian Amazonia). Earth Surface Processes and Landforms 32(2), 230-248.

Gautier E., Burnouf J., Carcaud N., Chambaud F., Garcin M. (2007) - Les interrelations entre les sociétés et le fleuve Loire depuis le Moyen Âge. In Trémolières M., Schnitzler A. (eds.), Protéger, restaurer et gérer les zones alluviales, pourquoi et comment,.Tec et Doc Lavoisier, 83-97.

Gautier E., Grivel S. (2006) - Multi-scale analysis of island formation and development in the Middle Loire River, France. In Rowan J.S., Duck R.W., Werrity A. (eds.), Sediment dynamics and the hydromorphology of fluvial systems. International Association of Hydrologic Science Publication 306, 179-187.

Gomez B., Phillips J. D., Magilligan F. J., James L. A. (1997) Floodplain sedimentation and sensitivity: summer 1993 flood, Upper Mississippi River valley. Earth Surface Processes and Landforms 22, 923-936.

Gurnell A. M., Peiry J.-L., Petts G. E. (2003) - Using historical data in fluvial geomorphology. In Kondolf G. M., Piégay H. (eds.), Tools in fluvial geomorphology. Wiley, $77-101$.

He Q., Walling D. E. (1996) - Use of fall-out $210 \mathrm{~Pb}$ measurements to investigate longer-term rates and patterns of overbank sediment deposition on the floodplains of lowland rivers. Earth Surface Processes and Landforms 21, 141-154.

Henrottay J. (1973) - La sédimentation de quelques rivières belges au cours des sept derniers siècles. Bulletin de la Société géographique de Liège, 9, 101-115.

Hooke J. M. (1995) - River channel adjustment to meander cutoffs on the River Bollin and River Dane, northwest England. Geomorphology 14, 235-253.

Hooke J. M., Mant J. M. (2000) - Geomorphological impacts of a flood event on ephemeral channels in SE Spain. Geomorphology 34, 163-180.

Horowitz A. J. (2006) - The effect of the 'Great flood of 1993' on subsequent suspended sediment concentrations and fluxes in the Mississippi River Basin, USA. In Rowan J. S., Duck R. W., Werrity A. (eds.), Sediment dynamics and the hydromorphology of fluvial systems. International Association of Hydrologic Science Publication 306, 110-119.

Houbrechts G., Petit F. (2003) - Utilisation des scories métallurgiques en dynamique fluviale : détermination de la compétence effective des rivières et estimation des vitesses de progression de leur charge de fond. Géomorphologie : relief, processus, environnement, 1, 3-12.

Houbrechts G. (2005) - Utilisation des macroscories et des microscories en dynamique fluviale : application aux rivières du massif ardennais. Thèse de géographie, université de Liège, $328 \mathrm{p}$.

Houbrechts G., Petit F. (2006) - Utilisation des microscories métallurgiques comme traceur de la sédimentation dans les plaines alluviales des rivières ardennaises. In Allée Ph., Lespez L. (eds.), L'érosion entre société, climat et paléoenvironnement Table ronde en l'honneur du Professeur René Neboit-Guilhot. Presses Universitaires Blaise-Pascal, Collection Nature et Société, 91-96.

Houbrechts G., Weber J.-P. (2007) - La sidérurgie proto-industrielle dans le bassin de la Lienne. De la Meuse à l'Ardenne 39, 34-63.
James C. S. (1985) - Sediment transfer to overbank sections. Journal of Hydraulic Research 23, 435-452.

Legleiter C. J., Kyriakidis P. C. (2008) - Spatial prediction of river channel topography by kriging. Earth Surface Processes and Landforms 33/6, 841-867.

Leopold L. B., Wolman M. G. (1957) - Rivers channel patterns braided, meandering and straight. U.S. Geological Survey Professional Paper 282-B, 35-85.

Leopold L. B., Wolman M. G., Miller J. P. (1964) - Fluvial processes in geomorphology. Freeman, $214 \mathrm{p}$.

Lewin J. (1978) - Floodplain geomorphology. Progress in Physical Geography 2, 408-437.

Malavoi J.-R. (1998) - Bassin Rhône-Méditerranée-Corse. Guide Technique $N^{\circ} 2$ : Détermination de l'espace de liberté des cours d'eau. Secrétariat Technique du SDAGE, Lyon, $40 \mathrm{p}$.

Marriott S. B. (1996) - Analysis and modelling of overbank deposits. In Anderson M. A., Walling D. E., Bates P. D. (eds.), Floodplain processes, Wiley, 63-93.

Martin Y., Church M. (1995) - Bed-material transport estimated from channel surveys: Vedder River, British Columbia. Earth Surface Processes and Landforms 20, 347-361.

Mertes L. A., Dunne T., Martinelli L. A. (1996) - Channel-floodplain geomorphology along the Solimóes-Amazon River, Brazil. Geological Society American Bulletin 180, 1089-1107.

Miall A.D. (1996) - The geology of fluvial deposits: sedimentology facies, basin analysis, and petroleum geology. Springer-Verlag, $582 \mathrm{p}$.

Nanson G. C., Croke J. C. (1992) - A genetic classification of floodplains. Geomorphology 4, 459-486.

Passega R. (1957) - Textures as characteristic of clastic deposition. American Association Petrology Geological Bulletin 9, 1952-1984.

Petts G. E., Möller H., Roux A. L. (1989) - Historical change of large alluvial rivers: western Europe. Wiley, 355 p.

Pizzuto J. E. (1987) - Sediment diffusion during overbank flows. Sedimentology 34, 301-317.

Reid L. M., Dunne T. (2003) - Sediment budgets as an organizing framework in fluvial geomorphology. In Kondolf G. M., Piégay H. (eds.), Tools in fluvial geomorphology. Wiley, 436-500.

Sabatier F. (2001) - Fonctionnement et dynamiques morpho-sédimentaires du littoral du delta du Rhône. Thèse de géographie, université de Provence (Aix-Marseille 3), 273 p.

Salo J., Kalliola R., Häkkinen I., Mäkinen Y., Niemelä Puhakka M., Coley P. D. (1986) - River dynamics and the diversity of Amazon lowland forest. Nature 322, 254-258.

Salvador P.-G. (1991) - Le thème de la métamorphose fluviale dans les plaines alluviales du Rhône et de l'Isère - Bassin de Malville et Ombillic de Moirans (Isère, France). Thèse de géographie, université Lyon 3, 498 p.

Schmidt K. H., Ergenzinger P. (1992) - Bedload entrainment, travel length, step lengths, rest period - Studied with passive (iron, magnetic) and active (radio) tracer techniques. Earth Surface Processes and Landforms 17, 147-165.

Sluse P., Petit F. (1998) - Evaluation de la vitesse de déplacement-de la charge de fond caillouteuse dans le lit des rivières ardennaises au cours des trois derniers siècles, à partir de l'étude des scories métallurgiques. Géographie Physique et Quaternaire, 52, 373-380. 
Steiger J., Gurnell A. M., Ergenzinger P., Snelder D. (2001) Sedimentation in the riparian zone of an incising river. Earth Surface Processes and Landforms 26, 91-108.

Stokes S., Walling D. E. (2003) - Radiogenic and isotopic methods for the direct dating of fluvial sediments. In Kondolf $\mathrm{G}$. M., Piégay H. (eds.), Tools in fluvial geomorphology. Wiley, 233-267.

Tricart J., Vogt H. (1967) - Quelques aspects du transport des alluvions grossières et du façonnement dans les lits fluviaux. Geografiska Annaler 49A, 351-366.
Walling D. E., He Q. (1998) - The spatial variability of overbank sedimentation on river floodplain. Geomorphology 24, 209-223.

Walling D. E., Owens P. N., Leeks G. J. L. (1997) - The characteristics of overbank deposits associated with a major flood event in the catchment of the River Ouse, Yorkshire, UK. Catena 31, 53-75.

Warner R. F. (1992) - Floodplain evolution in a New South Wales coastal valley, Australia: spatial process variations. Geomorpho$\log y$ 4, 447-458.

Article soumis le 11 juillet 2008, accepté le 26 février 2009. 